\title{
An overview of the Swedish Education System and supervision
}

Köksal BOZTAŞ*
Kemal Ŏguz ER ${ }^{* *}$

\begin{abstract}
Comparative Education Studies have an important value, especially in educational sciences and the findings from these studies give us useful information regarding the educational practices of various countries. Investigating of the other countries' educational systems, learning how to solve various problems faced in education in these countries,knowing their curiculum, administration, supervision and educational institutions and their structures can offer us different experiences and perspectives. In this study, Swedish Education System and the Structure of Inspection have been discussed and described through reviewing the related literature.
\end{abstract}

Keywords: Comparative education, Swedish Education System, inspection structure.

\footnotetext{
* Ph.D. Student in Balıkesir University, Institude of the Social Sciences, Department of Curriculum and Instruction. E-mail: koksalboztas@yahoo.com

** Assist. Prof. Dr., Balıkesir University, Necatibey Faculty of Education, Department of Curriculum and Instruction. E-mail: kemaloguzer@hotmail.com
} 


\section{SUMMARY}

Sweden is Northern European country, located in the coast of The Baltic Sea between Finland and Norway. 960 thousand of the 9.2 million population take compulsory education. Compulsory education, consisting of 21 local government in the country is for 9 years, and the average education time is 16 years. At the stage of compulsory education that having the school enrollment rate is \%99 in Sweden, the education is free of charge starting from pre-school until higher education. The Swedish Government provides financial assistance to the children going to school. Except for preschool education, the cost to a student approximately is 9523 U.S.Dollars. In addition,the government gives money every year from budget to the municipalities to carry out their educational services.

Municipalities in Sweden must provide secondary education (Second Term Middle School) to all students who complete the compulsory education with ''Education Law'. In addition, municipalities must provide the adult education in Sweden, too. The Swedish adult education, connecting to the municipalities, includes the adult education, learning disabled education and the Swedish education for immigrants. In Sweden, the responsibility for providing infrastructure to lifelong learning own a joint responsibility of central and local governments. Each municipality is responsible for organizing the adult education.

In Sweden, 400.000 students take a higher education as registered 30\% of graduating from high school continue to higher education in the country. The activities that are at the national level of colleges and universities are controlled by "National Agency for Higher Education"

"The Ministry of Education and Science" is responsible for educational planning in Sweden. There are two ministers in the Ministry of Education and Science. One of two ministers is responsible for schools, teaching and science; and the other one from pre-school and adult education. There are secretaries of state that are assigned via political way and responsible for all operations of ministry just below the Ministers.

The trend in Swedish education system is to remove the management from the centralization as possible. Municipalities are responsible for public education outside of higher education. In Sweden, the dominant view in education is determining of educational goals and ways to reach these goals by centralized authority and in favor of being maked detailed arrangements by the municipalities and schools. In other words, the opinion of giving autonomy to the municipalities and schools, when possible, is dominant. Municipalities have to prepare a quality report at the municipal level about belonging to themselves, all pre-school actvities, school-age children service and school activities Schools must also prepare a quality report. These reports are open to everyone, anyone who wants to get information about the municipality's or school's level of education can see these quality reports that are internal control type. 


\section{İsveç Eğitim Sistemi ve Denetim Yapısına Genel Bir Bakış}

Köksal BOZTAŞ*
Kemal Oğuz ER**

ÖZ. Karşılaştırmalı eğitim çalışmaları, özellikle eğitim bilimleri içinde önemli bir yere sahiptir. Bu çalışmalardan elde edilen bulgular temelde çeşitli ülkelerin eğitim uygulamaları hakkında bizlere yararlı bilgiler verir. Başka ülkelerin eğitim sistemlerini incelemek, eğitimde karşılaşılan çeşitli sorunların bu ülkelerde nasıl çözüldüğünü öğrenmek, onların program, yönetim, denetim ve eğitim kurumlarını ve yapılarını bilmek, bize değişik deneyimler ve bakış açıları sunabilir. Bu çalışmada, İsveç Eğitim Sistemi ve Denetim Yapısı çalışma konusu olarak ele alınmış ve alanyazın çalışması yoluyla incelenerek var olan durum betimlenmeye çalışılmıştır.

Anahtar Sözcükler: Karşılaştırmalı eğitim, İsveç Eğitim Sistemi, denetim yapısı.

* Doktora Öğrencisi, Balıkesir Üniversitesi Sosyal Bilimler Enstitüsü Eğitim Programları ve Öğretim Bilim Dalı. E-posta: koksalboztas@yahoo.com

${ }^{* *}$ Yrd.Doç.Dr., Balıkesir Üniversitesi Necatibey Eğitim Fakültesi Eğitim Bilimleri Bölümü.

E-posta: kemaloguzer@hotmail.com 


\section{GİRIŞ}

Türkiye, Avrupa Birliği (AB) aday ülkeleri arasında yer almaktadır. Uzun süredir devam etmekte olan bu süreçte, $A B$ 'ye uyum sağlamak amaciyla birçok yasal ve örgütsel düzenlemeler yapılmıştır. Eğitim alanında da uyum sağlanmaya çalışılan bir sistemin tüm boyutlarıyla ele alınması ve gerektiğinde eleştirel gözle incelenmesi gerekmektedir. Bu bağlamda, köklü değişimleri uzun süredir başarıyla yürüten ve 1995 yılından bu yana $\mathrm{AB}$ üyesi olan (Kilimci ve Riis, 2008, 256) İsveç'in eğitim sisteminin incelenmesinin, Türk Eğitim Sistemine önemli katkılar sağlayabileceği düşünülmektedir.

İsveç, Baltık Denizi kıyısında, Finlandiya ile Norveç arasında yer alan Kuzey Avrupa ülkesidir. Yüzölçümü 449,964 km² dir. Para Birimi İsveç Kronu'dur. Ülkede en yaygın konuşulan dil İsveççe'dir. Fransızca, Almanca ve Fince de konuşulmaktadır. Ancak küreselleşmenin etkisiyle İngilizce çok yaygın bir biçimde konuşulmaktadır (MEB Rehber, 2006, 116). Başkenti Stockholm'dür ve 21yönetsel bölgeden oluşur. 2009 verilerine göre nüfusu 9,2 milyondur ve bu nüfusun 960 bini zorunlu eğitimde öğrencidir (Eurydice, 2010b, 1).

İsveç eğitim sistemi en merkezi sistemlerden biri iken, yapılan değişikliklerle belirgin bir şekilde yerinden yönetime kavuşturulmuştur. Bugün İsveç okulları öğretim saatlerinin düzenlenmesi, öğretim içeriğinin belirlenmesi ve kullanılacak yöntemlerin seçimi bakımından diğer ülkelere oranla daha özerktir (Lundahl, 2005, 1; Skolinspektionen, 2011a, 7). Devlet, eğitim sistemindeki gelişimi ve ilerlemeyi sağlamak için eğitimin izlenmesi ve değerlendirilmesinden sorumludur. Ayrıca öğrencilere maddi yardım sağlamaktadır. İsveçli bir öğrenci ortalama 16 yıl öğrenim görmektedir. Okul öncesi eğitim dışında bir öğrencinin maliyeti 2009 yılında ortalama 9,523 Amerikan Dolarıdır (OECD, 2010, 1). Kamu çocuk hizmeti (okul öncesi çocuk bakımı) dışında devlete ait ilk, orta ve yüksek öğrenim kurumlarında eğitim ücretsizdir. İsveç’te yükseköğretim de ücretsizdir (Ada ve Üstün, 2008, 149; Eurydice, 2010b, 1).

\section{Eğitim Basamakları}

İsveç Eğitim Sistemi: Okul Öncesi, İlköğretim (Zorunlu Eğitim), Ortaöğretim ve Yüksek Öğretim olmak üzere dört temel basamaktan oluşmaktadır (Şema 1). 
Şema1. İsveç Eğitim Sistemi

\begin{tabular}{|r||c|c|}
\hline \multicolumn{3}{|c|}{ ISVEÇ EĞITIM SISTEMININ ŞEMASI } \\
\hline Yaş & \multicolumn{2}{|c|}{ Master, Doktora } \\
\hline 26 & M \\
\hline
\end{tabular}

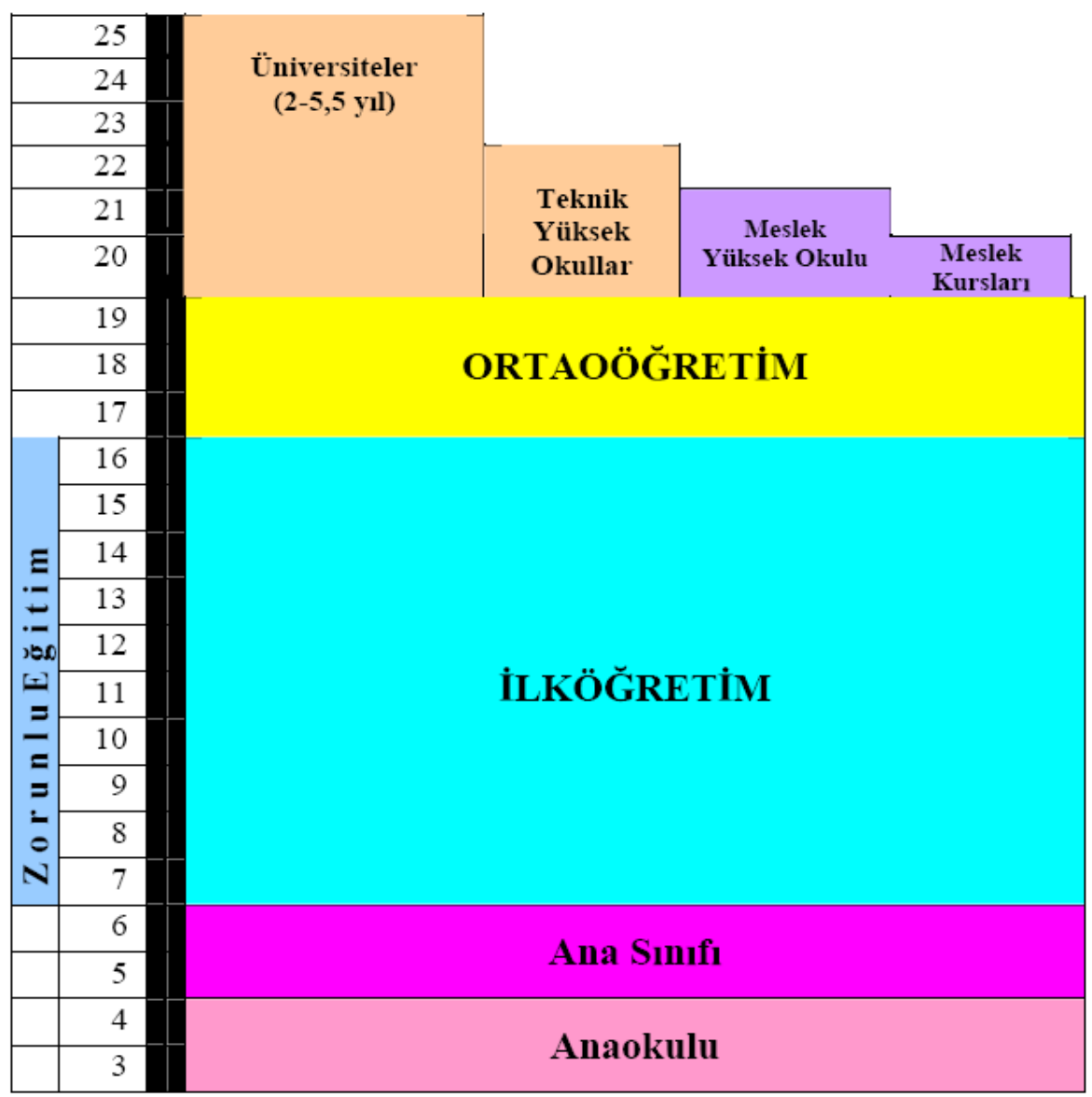

MEB TKB. (2007). Türkiye ve Avrupa Birliği Ülkelerinde Eğitim Denetimi. Ankara: MEB Teftiş Kurulu Başkanlığı Yayını. S. 115 - 116 


\section{Okul Öncesi Ĕ̆itimi}

İsveç’te okul öncesi eğitime "Kamu Çocuk Hizmeti" adı verilmektedir. $\mathrm{Bu}$ eğitim kamuya aittir ve Kamu Hizmetleri Kanunu'na göre yürütülmektedir. Okul öncesi eğitim merkezlerinin sorumluluğunu Eğitim ve Bilim Bakanlığı 1996 yılında devralmıştır (EIU Views Wire, 2007, 1).

Altı yaş ve üstü tüm çocuklar ve aynı zamanda dört yaştan itibaren engelli çocuklar okul öncesi eğitimden en az bir y1l süreyle yararlanmaktadırlar. $\mathrm{Bu}$ eğitimden yararlanıp yararlanmamak isteğe bağlı olmasına karşın, bu hizmeti vermek yerel yönetimler için zorunludur. Kamu çocuk hizmeti belediyelerden ve ailelerden alınan katkılarla ortaklaşa finanse edilmektedir. Okul öncesi kurumlarının dörtte biri özel, geri kalanları belediyelere aittir (EIU Views Wire, 2007, 1). Okul öncesi eğitimde yalnızca altı yaş grubu çocukların eğitimi ücretsizdir. Çocuk başına maliyet, OECD ülkeleri arasında Danimarka'dan sonra ikinci sirada yer almaktadır (EIU Views Wire, 2007, 1). 18 ayını dolduran tüm çocuklar bu hizmetten yararlanabilirler. Okul-sonrası merkezler ise 6-12 yaş arası çocuklara yönelik hizmet vermektedir (EIU Views Wire, 2007, 1).

\section{İlköğretim (Zorunlu Eğitim)}

İsveç'te zorunlu ilköğretim yasal olarak 1842 yılında başlatılmıştır (MEB DİGM, 2006, 137; Erginer, 2007, 104). Zorunlu ilköğretim okulları (Grundskola) günümüzde 9 yıllık olup; "alt basamak", "orta basamak" ve "üst basamak" isimleriyle üçer yıl süreli, üç öğretim basamağına ayrılmıştır (Ültanır, 2005, 17; MEB Rehber, 2006, 114; Gülcan, 2005, 196; MEB DİGM, 2006, 137). 1962 reform kanunuyla kabul edilen Grundskola, eski yedi yıllık "Folkskola" ile beş yıllık "Realskola" nın yerini almıştır (Aytaç, 1970, 74). Zorunlu eğitim sistemi, ülkenin kuzeyindeki Sami dilinde konuşan çocuklar için açılan Sami okullarını (bazı engelli çocuklar, örneğin işitme, görme ve konuşma yeteneği kısıtlı çocuklar için açılan özel okullar) ve zihinsel engelliler için hizmet veren okulları da içerir (Eurydice, 2007; MEB DİGM, 2006, 137).

İsveç'te zorunlu eğitim 7-16 yaş arası çocuklara yönelik olmakla birlikte, 1991 yılından bu yana çocukların altı yaşında okula başlamaya hakları bulunmaktadır; ancak bunu ailelerin arzu etmesi (Ulusavaş, 2000, 3; sverigeturism, 2008, 1) ve belediyenin bu hizmeti sunmak için kapasitesinin yeterli olması gerekir. Okullaşma oranı zorunlu eğitim kademesinde \% 99' dur. 2004-2005 yılları arasında 1.02 milyon öğrenci, 4963 ilköğretim okulunda öğrenim görmüştür (EIU Views Wire, 2007, 2). 2004 y1lında zorunlu eğitimde bulunan öğrencilerin \% 5'i özel okullarda eğitim görmüştür 
(George ve Green, 2004, 6). Bu rakam 2008 y1lında \% 10'a çıkmıştır (Eurydice, 2010b, 1). İsveç'te zorunlu eğitimde karma eğitim yapılır. Öğretim yılı iki dönemden oluşur. En az 178 iş günü öğretim yapılır ve öğretim y1lı 12 haftalık tatil ile birlikte toplam 40 haftadan oluşur (MEB Rehber, 2006, 114; Erginer, 2007, 99-100).

\section{Ortaöğretim (İkinci Dönem Orta Okul)}

İş dünyasının ve genç insanların gereksinim ve isteklerini karş1layabilmek için Gymnasieskoldn denilen okullarda verilen eğitimdir. Belediyeler, "Öğretim Kanunu" ile zorunlu eğitimi bitiren öğrencilere ortaöğretim sunmak zorundadırlar (Erginer, 2007, 100).

İsveç'te 1990'l1 yıllardan sonra özel okullarda artış yaşanmıştır. Devletin öğrenim gören öğrenci başına destek vermesi bu artışta etkili olmuştur. 2005 yılında zorunlu eğitimi bitiren öğrencilerin \% 7'si ve ortaöğretim öğrencilerinin \% 13'ü özel okullara geçmiştir (EIU Views Wire, 2007, 2).

Zorunlu eğitim dönemi, gencin seçeceği yaşama yönelik öğrenim gereksinimleriyle ilgili bir uyumlandırma basamağıdır. Bu dönemde genç, ileride nasıl bir eğitim alacaksa, önce ona uyum sağlamalıdır. İsveç'teki üç yıllık orta basamak okulu da bu görevi üstlenir (Ültanır, 2005, 17). Ortaöğretim eğitimi birçoğu belediye sorumluluğundaki okullarda gerçekleşmektedir. Belediyeler, zorunlu eğitimlerini tamamlayan tüm öğrenciler için ortaöğretim ikinci dönemini sağlamak zorundadırlar (Erginer, 2007, 100).

\section{Yükseköğretim}

İsveç’te yükseköğretim, devlete bağlı on dört üniversite (universitet) ve yirmi iki yüksek okulda (högskolor) yürütülmekle beraber, bağımsız yükseköğretim kurumları da bulunmaktadır (Eurydice, 2011, 90). İsveç’te üniversite ve yüksekokulların ulusal düzeydeki etkinliklerini "Yüksekögretim Ulusal Ajansı" (Högskoleverket) denetler (Eurydice, 2011, 90). Başka bir deyişle yükseköğretimin kalitesini ve mevzuata uygunluğunu incelemek, eğilimleri ve gelişmeleri takip etmek, gerekli bilgiyi sağlamak ve yurtdış1 yeterliliklerini takip etmek bu ajansın görevleri arasındadır (Hsv, 2011, 1).

İsveç'te zorunlu eğitim ve ortaöğretim okullarını bitiren öğrencilerin yaklaşı \% 30'u yükseköğretime devam etmektedir. İsveç üniversitelerinde yaklaşı 400000 kayıtlı öğrenci bulunmaktadır (Reingen, 2011, 1). İsveç’te 19 yaşın altında üniversiteye gitme oranı diğer ülkelerden daha düşüktür (EIU Views Wire, 2007, 2). 


\section{Yetișkin Eğitimi}

İsveç'de yetişkin eğitimi, belediyeler tarafından yapılmaktadır. Yetişkin eğitimi: "yetişkin eğitimi", "öğrenme engelliler eğitimi" (Särvux) ve göçmenler için verilen "İsveççe eğitimi" olmak üzere (sfi) üç alanda yapılmaktadır (Sweden, 2011a, 1). Öğrenme engelliler ve yetişkin eğitiminin amac1, bireylerin okulda edindikleri bilgilerinin, deneyimlerinin ve yeteneklerin geliştirilmesidir (Government Offices of Sweden, 2011b, 1). Göçmenlere yönelik İsveççe eğitiminin amacı ise, göçmenlere temel İsveç dilini öğretmektir. Normal koşullarda, göçmenlerin bir belediye bölgesinde ikametinden itibaren üç ay içerisinde bu eğitimin başlaması gerekir ve bu eğitim belediyelerin zorunlu görevleri arasındadır (Government Offices of Sweden, 2011c, 1).

İsveç'te belediyelere bağlı yetişkin eğitiminin uzun bir geçmişi vardır. Gereksinim duyan yetişkinlere zorunlu ve ortaöğretim seviyesinde verilen eğitimin yanı sıra mesleki eğitim de verilir (MEB Rehber, 2006, 114; EIU Views Wire, 2007, 2).

İsveç'te hayat boyu öğrenmeye altyapı sağlama sorumluluğu, merkezi ve yerel yönetimlerin ortak sorumluluğundadır. Her belediye yönetimi, bünyesinde yetişkin eğitimi düzenlenmesini sağlamakla yükümlüdür. İsveç "Esnek Öğrenim Ajansı" (Nationellt centrum för flexibelt lärande) uzaktan eğitim için yeni yöntemler geliştirmekte ve kurslar düzenlemektedir (Eurydice, 2011, 109).

\section{Eğitim Yönetimi}

Merkezi Düzey: İsveç Parlamentosu ve hükümet, eğitim kanunları çerçevesinde merkezi planlama ve bunların uygulanma şeklini tespit ederek, eğitimde belirlenen amaçlara erişilmesini sağlar. Hükümet, yıllık bütçeden, belirtilen miktar üzerinden belediyelerin değişik etkinlikleri için ödenek verir ve program geliştirme çalışmalarının yürütülmesini sağlar (MEB Rehber, 2006, 114).

İsveç'te eğitim planlamasından "Ĕgitim ve Bilim Bakanlı̆̆l" sorumludur. Eğitim geleneksel olarak devlet tarafindan organize edilir. Eğitim ve Bilim Bakanlığında iki bakan bulunur. Bir bakan okullardan, öğretimden ve bilimden; diğeri ise okul öncesi ve yetişkin eğitiminden sorumludur (Inca, 2010, 1). Bakanların hemen altında politik yoldan atanmış, bakanlığın tüm işleyişinden sorumlu devlet sekreterleri vardır ve bakanlar birçok politik danışmana sahiptir. Ancak, İsveç Eğitim ve Bilim Bakanlı̆̆g'nda "yönetsel ve hukuk işlerinden" sorumlu bir Genel Müdür vardır ve bu müdür bakanlık içerisinde politik olmayan en yüksek konuma 
sahiptir. Genel müdür bakanlık içindeki tüm işlerin ve işlemlerin kanuna uygun yapılmasından, kanun ve yönetmeliklerin tasarılarını hazırlamaktan sorumludur (Government Offices of Sweden, 2010, 1).

İsveç’te, ulusal düzeyde politika üretmeye yardımcı olan ve uluslararası işbirliğini artırmayı amaçlayan birçok örgüt bulunmaktadır. "İsveç Ulusal Eğitim Ajansı" (Skolverket) ve "İsveç Okul Geliştirme Ulusal Ajansı" (Myndigheten för skolutveckling) kendi sorumluluk alanlarında uluslararası çalışmalara katılmakla görevlidirler (Eurydice, 2011, 180). Örneğin; İsveç Ulusal Eğitim Ajansı, ulusal okul sistemi ve kamunun organize ettiği okul öncesi ve okul çağı çocuk etkinliklerinin yönetim sorumluluğunu üstlenir. $\mathrm{Bu}$ ajans, okul sisteminin, okul öncesi ve okul çağı etkinlikleri ile yetişkin eğitiminin takip edilmesi, geliştirilmesi ve değerlendirilmesi sorumluluklarını üstlenerek eğitimde amaçlara ulaşılmasına yardım eder (Government Offices of Sweden, 2011d, 2).

Yerel Düzey: İsveç eğitim sisteminde eğilim, yönetimi olabildiğince merkezilikten uzaklaştırmak olarak benimsenmiştir. Üniversiteye kadar kamu eğitiminden belediyeler sorumludur. Her eyalet yerel koşullarına uygun bir çalışma planı hazırlamakla yükümlüdür. $\mathrm{Bu}$ plan okul yöneticilerinin olduğu kadar öğretmen ve öğrencilerin de katkılarıyla hazırlanır (Ulusavaş, 2000, 3). İsveç'te eğitimde egemen olan görüş, merkezi otoritenin amaçları ve bu amaçlara ulaştıracak yolları belirlemesi, ayrıntılı düzenlemelerin ise belediyeler ve okullar tarafından yapılmasıdır. Başka bir deyişle belediye ve okullara mümkün olduğunda özerklik verilmesi görüşü hâkimdir (insight, 2011, 2).

Belediyeler, devletin eğitim kanununda belirlediği çerçeve içinde eğitimsel etkinlikleri ve ulusal eğitim programlarını yürütmekten sorumludur. Ulusal amaçlara ulaşılabilmesi için okul sisteminin nasıl düzenleneceği konusunda belediyeler oldukça geniş yetkilere sahiptir. Bunların dışında okullara gerekli kaynakları ve koşulları sağlamak, denetlemek ve gözlemlemek gibi sorumlulukları da vardır (Government Offices of Sweden, 2011e, 1).

\section{Eğitim Denetimi}

İsveç’te "eğitim denetimi", belediyelerin ve okulların "Eğitim Kanunu"nda öngörülen sorumluluklarını yerine getirip getirmediğini kontrol etmek anlamına gelmektedir. Aynı zamanda ulusal hedefler ve ulusal eğitim programına göre eğitimsel etkinliklerin ve okulların nasıl yürütüldüğü de kontrol edilir. İsveç denetim modeli değerlendirme, kontrol ve hesap verilebilirlik ihtiyaçlarını karşılamak üzere büyük oranda yerinden yönetim ve yerel sorumluluğa dayalıdır (Skolinspektionen, 2011a, 1). 
İsveç, 2008 y1lında okullardaki disiplin problemleri ve kalite düşüşü nedeniyle eğitim denetiminde yapısal değişikliğe gitmiştir. 2008 öncesinde "Ulusal Ĕgitim Ajansl" (Skolverket) okul sisteminin; "Ulusal Yüksek Öğretim Ajansı" (Högskoleverket) ise yüksek eğitimin denetiminden sorumlu idi (Eurydice, 2010a, 148; Skolinspektionen, 2011a, 1).

Ancak 1 Ekim 2008'den itibaren "Ulusal Okullar Denetim Kurulu" (Skolinspektionen), eğitimsel denetim yapmak, şikâyetleri incelemek ve özel okulları onaylamak amacıyla kurulmuş ve çalışmaya başlamıştır. "Okul Geliştirme Ulusal Ajansı" (Skolutvecklingsmyndigheten) ise bu yeni örgütün kurulmasıyla feshedilmiştir (inca, 2011, 1; skolinspektionen, 2011a, 1-2). Bu değişimde Ulusal Eğitim Ajansı'nın varlığı devam etmiş ama görev alanları -denetim görevi sona ermiş- sınırlanmıştır (skolinspektionen, 2011a, 18). Ulusal Yüksek Öğretim Ajansı'nın yapısında ve işlevinde ise herhangi bir köklü değişim yaşanmamıştır. Böylece İsveç okul sistemi disiplin problemleri ve kalitedeki düşüş karşısında önceki döneme kıyasla sert yaptırımlar uygulama yoluna gitmiştir (Eurotopics, 2008, 1; skolinspektionen, 2011a, 10).

İsveç’te "eğitimsel denetim" düzenli gözlem ve tematik kalite değerlendirme yoluyla yapılmaktadır. Düzenli gözlemin odak noktas1, kanuna uygunluk ve amacı Eğitim Kanunu'nda her bireye sağlanan hakların sağlanmasıdır. Tematik kalite değerlendirmesinin odağı, okulların performansı ve çıktılarıyla ilişkili olarak öğretme ve öğrenme süreçlerinin kalitesidir (Skolinspektionen, 2011a, 2). Denetim yoluyla eğitimdeki eşitsizliklerin önlenmesine çalış1lır. Çünkü yerel yönetimlerin büyük sorumluluğa sahip olduğu yerinden yönetim sistemlerinde birimler arasında farklılaşmaların ve eşitsizliklerin görülme olasılığ 1 riski vardır (Skolinspektionen, 2011a, 7).

\section{Eğitim Denetiminde Örgütsel Yapı}

İsveç’te eğitimin denetim görevini, Ulusal Eğitim Ajansı'ndan “Ulusal Okullar Denetim Kurulu” devralmıştır. Ulusal Okullar Denetim Kurulu, Eğitim ve Bilim Bakanlığı'na bağlı özerk ve merkezi bir örgüttür (Skolinspektionen, 2011a, 6) ve okul öncesi eğitimin, zorunlu eğitimin, Sami okullarının, özel eğitimin, okula giden öğrencilerin güvenliğinin, okulların yönetiminin ve yetişkin eğitiminin denetiminden sorumludur. Denetim Kurulu yerel yönetimlerin ve özel okulların yürürlükteki mevzuata uygun davranıp davranmadığını da kontrol eder. Denetim Kurulu'nun okullarda çalışan herhangi bir görevliyi işten atma, işe alma ya da yönetsel herhangi bir yetkisi yoktur (Skolinspektionen, 2011a, 17). 
"Çocuk ve Öğrenci Ombudsmanlı̆̆ Ofisi" (Barn- och elevombudsmannen - BEO) her ne kadar özerk çalışmakta ise de, Ulusal Okullar Denetim Kurulu'nun bir parçasıdır ve okul öncesi ve okul çağı çocukların istismarına karşı mücadele eder. "Ë̆gitim Temyiz Heyeti" (Överklagandenämnden - ÖKN) de Ulusal Okullar Denetim Kurulu'na bağlı ancak özerk çalş̧an bir birimdir ve yetkili birimlerin aldıkları kararları temyiz edebilir (Skolinspektionen, 2011b, 1; Eurydice, 2010b, 2). Bu görevlerin yanı sıra Ulusal Okullar Denetim Kurulu, psikolojik rahatsızlı̆̆ bulunan gençlere yönelik eğitim hizmeti veren "Ulusal Bakım Kurulunun" ve "Ísveç Cezaevi ve Gözetim Servisi"nin de eğitim denetiminden sorumludur (Skolinspektionen, 2011a, 8).

Merkezi Stockholm'de bulunan Denetim Kurulu'nu genel müdür yönetir ve genel müdür hükümet tarafindan atanır. Göteborg, Linköping, Lund, Stockholm ve Umeå' da bölge müdürlükleri bulunur ve bunlar kendi bölgelerinde denetimde bulundukları gibi diğer bölgelerdeki denetimlere de kat1labilirler (Skolinspektionen, 2011a, 13, 23).

Yükseköğretim örgütlerinin gözlenmesinden, değerlendirilmesinden ve denetiminden sorumlu olan birim "Yüksekögretim Ulusal Ajansı"”dır (Högskoleverket). Ajans, aynı zamanda yükseköğretimde uluslararası işbirliğinden ve öğrencilere gerekli bilgi desteğinden de sorumludur (Eurydice, 2010b, 2).

\section{Denetim Süreci}

Dış Denetim: Eğitim programını ve ulusal hedefleri belirlemek İsveç Parlamentosuna ve hükümetine ait iken, belirlenen çerçeve içerisinde eğitim vermek yerel yönetimlere ve özel okul yönetimlerine aittir. Gerek devlet, gerek özel okulların belirlenmiş çerçeve içerisinde eğitim yapıp yapmadıklarını denetlemek, başka bir deyişle Eğitim Kanunu'na uyulup uyulmadığını kontrol etmek görevi ise "Ulusal Okullar Denetim Kurulu"na aittir (Skolinspektionen, 2011a, 7).

Bir öğrenci, velisi ya da üçüncü bir kişi, verilen eğitim ile ilgili eleştiri ya da şikayeti olduğunda Ulusal Okullar Denetim Kurulu'na başvuruda bulunabilir. Ulusal Okullar Denetim Kurulu, başka kaynaklardan bilgi ulaşması halinde kendi inisiyatifiyle de soruşturma başlatabilir. Soruşturma, ilgili birimin yazılı uyarılması ve gereğinin yapılması isteğiyle sonuçlanabilir (Skolinspektionen, 2011c, 1). Bu kurula öğrenci velilerinden ve diğer kaynaklardan yıllık 1400 şikâyet gelmektedir (Skolinspektionen, 2011a, 10).

Ulusal Okullar Denetim Kurulu belirli bir başvuru haricinde düzenli denetim yapmakta ve mevzuata uygunluğu sağlamaktadır. 2003 yılında 
Ulusal Eğitim Ajansı'na verilen ve altı yıl içerisinde tamamlanması gereken denetim görevini, Ekim 2008'de kurulduktan sonra Ulusal Okullar Denetim Kurulu devralmıştır. Söz konusu denetim hem hukuk hem de kalite denetimidir (Skolinspektionen, 2011a, 8).

Düzenli denetimlerde öğrencilerin ulusal eğitim programının hedeflerinden hangilerine ulaştıkları, öğretmenlerin her bir öğrencinin bireysel ihtiyaçlarına öğretimlerini nasıl uyarladıkları da incelenir. Bunların dışında demokratik bir toplumun normlarını ve değerlerini öğrencilere kazandırmada okulun düzeyi ve yönetim durumuna bakılır (skolinspektionen, 2011a, 9). Düzenli denetim sonucunda gerek görüldüğü durumlarda sorumlu birimden işlem yapılması istenebilir. Eğer özel okul bu isteği yerine getirmez ise okulun çalışma izni iptal edilebilir (Skolinspektionen, 2011c, 1).

Kalite değerlendirme yoluyla Denetim Kurulu belirli alanlarda derinlemesine inceleme yapmaktadır. $\mathrm{Bu}$ inceleme bir okulda bir dersin öğretimi gibi dar bir alan olabileceği gibi bir okulun durumu gibi geniş de olabilir. Varılacak yargı, okulun gözlem belgelerinin yanı sıra araştırma sonuçlarına da dayanır. Eğer Denetim Kurulu bir aksaklık görecek olursa düzeltilmesini isteyebilir ve durumun geliştirilmesi için önerilerde bulunabilir. Aynı zamanda Denetim Kurulu denetim sürecinde karşılaştı̆̆ 1 iyi uygulamaları örnek gösterebilir (Skolinspektionen, 2011c, 1). Kalite değerlendirme dışarıdan yapıldığı gibi ayrıca birimlerin kendilerince de yapılabilir. Denetleme etkinliklerinin yaklaşı yarısı kalite değerlendirme çalışmalarıdır (Skolinspektionen, 2011a, 15).

İsveç'te denetim süreci dört aşamada gerçekleştirilir: Hazırlık, ziyaret, analiz ve geri bildirim. Hazırlık aşamasında mevcut raporlar, istatistiksel veriler ve her türlü belge ya da doküman incelenir. Ziyaret iki denetçi tarafindan yerine getirilir, asla yalnız denetlemezler ve denetleme bir ya da iki gün sürer. Ziyaretin bitiminde denetçiler düşüncelerini sözlü olarak açıklarlar. Analiz sonucu oluşturulan kesin rapor birkaç hafta içinde açıklanır ancak öncesinde sorumlu yöneticilere ön rapor açıklanarak düşünceleri alınır. Kesin rapordan sonra son karar alınır. Eksikliği görülen birimler, eksikliği gidermek için yaptıklarını yazılı olarak üç ay içerisinde bildirmek zorundadır. Denetim Kurulu bu durumu yeterli görürse denetleme sonuçlanmış olur, yeterli görülmezse Denetim Kurulu sorumlu otoriteden ek önlemler (yaptırım) isteyebilir (Skolinspektionen, 2011a, 10-13).

Yapılan denetimler sonunda, sonuçlar okullara göre raporlaştırılır ve yayınlanır. Düzenli denetimin raporu standart iken kalite değerlendirme raporları farklılaşabilir. Düzenli denetim raporunda belediye düzeyine de yer verilir. Raporlarda denetime dayalı olarak resmi karar da yer alır. Tüm raporlar kamuya açıktır ve basılmasının yanı sıra internette de yayınlanır (skolinspektionen, 2011a, 22). 
Denetçiler öğretmenin ya da başka bir görevlinin performansını ölçmezler ancak kötü performansla karşılaşırlarsa sorumluyu okul yöneticisine bildirirler (Skolinspektionen, 2011a, 17). Denetim Kurulu, yeni açılacak özel okullara izin vermekle yetkilidir ve izin verilen özel okulların açılmasından hemen sonra da açılan okulları denetlemektedir. Yukarıda sayılan denetim süreçlerine ek olarak, Denetim Kurulu, zorunlu eğitim ve ortaöğretimde öğrencilere uygulanacak olan ulusal testleri de kontrol etmektedir (skolinspektionen, 2011c, 1).

Yükseköğretimde ise "Yüksekögretim Ulusal Ajansı" (Högskoleverket) yükseköğretim örgütlerinin diş denetimini yapmaktadır. İsveç’te yükseköğretim seviyesinde genel ya da mesleki yeterlik ve lisansüstü programlarının ve konuların değerlendirilmesi her altı yılda bir yapilmaktadır (Eurydice, 2011, 90).

İç Denetim: Her belediye kendisine bağlı tüm okul öncesi, okul çağı çocuk hizmeti (school-age child care) ve okul etkinlikleri hakkında belediye düzeyinde bir kalite raporu hazırlamak zorundadır. Her okul ise işleyişe ilişkin bir kalite raporu hazırlamak zorundadır. Söz konusu raporlar herkese açıktır. Okulun ya da belediyenin eğitim düzeyi hakkında bilgi almak isteyen herkes iç denetim türü olan bu kalite raporlarını görebilir. Ancak yukarıda açıklanan kalite raporlarının okullarca tam anlaşılamadığı ve amacına ulaşamadığı, Denetim Kurulu'nca itiraf edilmektedir (Skolinspektionen, 2011a, 14).

\section{Denetim Elemanları}

Denetim Kurulu'nda istihdam edilen denetçilerin, öğretmenlik, okulda ya da belediyede eğitim yöneticiliği ya da eğitim araştırmacısı gibi geçmiş deneyimleri vardır. Ancak son zamanlarda farklı alanlardan da denetçiler işe alınmaktadır. Denetçiler üniversite ya da eşdeğer düzeyde eğitim almış olmak zorundadır. İşe alma sürecinde belli bir sınav ya da test yoktur. İşe alındıkları gün başlayan altı aylık adaylık süresi sonunda Denetim Kurulu, bu kişilerin işe denetçi olarak devam etmeleri ya da etmemeleri konusunda karar verir (Skolinspektionen, 2011a, 24-25).

Tüm denetçiler değişik türde eğitimlere tabi tutulurlar. İlk önce çalışacakları bölge müdürlüğünde kıdemli bir denetçi rehber (mentor) görevlendirilir. Okul ziyaretlerine yeni denetçi mutlaka kıdemli bir denetçi ile birlikte gönderilir. Grup olarak yeni denetçilere Stockholm'de üç günlük tanıtım eğitimi de verilir. Bundan başka bölge müdürleri, denetçilere hizmet içi eğitim verilmesinden sorumludurlar. Ayrıca tüm bölgelerdeki denetçileri kapsayan ve zorunlu olan hizmet içi eğitimler de vardır (skolinspektionen, 2011a, 25). 


\section{SONUÇ}

İsveç eğitim sistemi özerk bir yapıya sahiptir. Zorunlu eğitimden başlayarak tüm kademelerde eğitim ücretsiz sunulmaktadır. Yükseköğretime kadar olan tüm kademelerde eğitim olanağını sağlamak yerel yönetimlerin sorumluluğundadır. Yükseköğretim ise üniversiteler ve yüksek okullarda (högskolor) verilmektedir. Zorunlu eğitimin yanı sıra, yerel yönetimler yetişkin eğitimi de vermek zorundadırlar.

Zorunlu eğitimin İsveç’te uzun bir geçmişi vardır ve süresi dokuz yıldır. Zorunlu eğitimin önemli amaçlarından birisi öğrencileri geleceğe yönlendirmedir. Bu özellik ortaöğretimde de devam etmektedir. Ortaöğretim iş dünyasının ve gençlerin gereksinimlerini karşılayacak şekilde örgütlenmiştir. Gerek iş hayatına atılmış olanlara, gerek öğrenme güçlüğü çekenlere ve gerekse göçmenlere yönelik olarak yetişkin eğitimi düzenlenmektedir.

Eğitim yönetimi yerinden yönetim niteliği taşımaktadır. Dolayısıyla merkezi yönetim amaçları belirleyip kaynak aktarımını sağlarken, yerel yönetimler eğitim hizmetinin sunulmasından sorumludurlar. Eğitim ve Bilim Bakanlığı eğitimin planlanmasından sorumludur ve bünyesinde özerk birimler bulundurur. Bu birimler arasında İsveç Ulusal Eğitim Ajansı, yönetim boyutunda en önemli birimdir ve okul öncesi, okul sistemi ve yetişkin eğitiminin geliştirilmesinden ve değerlendirilmesinden sorumludur. Yerel yönetimler yükseköğretim dişındaki tüm eğitim hizmetlerinin yönetiminden sorumludurlar.

İsveç eğitimini denetleme görevi, 2008 değişikliği ile birlikte yeni kurulan Ulusal Okullar Denetim Kurulu'na devredilmiştir. Eğitim yönetiminde ve denetiminde görülen yerinden yönetim 2008 değişikliğiyle denetim boyutunda merkezileşmeye doğru yaklaşmıştır. Artan önlemler eğitimin kalitesinin düştüğü yönündeki endişelerden kaynaklanmaktadır. Ulusal Okullar Denetim Kurulu, düzenli denetim, şikâyetleri inceleme ve kalite değerlendirme süreçleriyle denetim görevini yerine getirmektedir. Eğitimin denetimi konusunda İsveç'te süreci iyileştirmeye yönelik tartışmalar devam etmektedir. 


\section{KAYNAKLAR}

Ada, Ş. ve Üstün, A. (2008). İsveç Eğitim Sisteminin İncelenmesi. Atatürk Üniversitesi Kâzım Karabekir Eğitim Fakültesi Dergisi, Sayı:17, ss. 146-173.

Aytaç, K. (1970). Okul Reformlarl ve Okul Kuruluş Sistemlerinde Demokratlaşma Temayülleri. İstanbul: Milli Eğitim Basımevi.

EIU Views Wire. (2007). Sweden: Education The Economist Intelligence Unit Ltd. [Online] Retrieved on:19.October.2007, at URL: http://proquest.umi.com/pqdweb?did $=1264350211 \quad \&$ sid $=\quad 1 \& \mathrm{Fmt}=3$ $\&$ clientId $=46703 \&$ RQT $=309 \&$ VName $=$ PQD.

Erginer, A. (2007). Avrupa Birliği Eğitim Sistemleri. Ankara: Pegem A Yayıncılık. Eurotopics. (2011). Fines for Bad Schools. [Online] Retrieved on 02.February.2011,atURL: http://www.eurotopics.net /en/ archiv/ aehnliche/archiv_article/ARTICLE36937-Fines-for-bad-schools.

Eurydice. (2007). [Online] Retrieved on:01.September.2007, at URL : www.eurydice.org/ Eurybase/ Application frameset.asp?Country= $\mathrm{SW} \&$ language $=\mathrm{EN}$

Eurydice. (2010a). The Education System in Sweden. [Online] Retrieved on 25.September.2010, at URL: http://eacea.ec.europa.eu/education /eurydice/documents/ eurybase/eurybase full_reports/ SEEN .pdf

Eurydice. (2010b). National Summary Sheets on Education Systems in Europe and Ongoing Reforms. [Online] Retrieved on 24.September.2010, at URL: http://eacea.ec.europa.eu /education/ eurydice/ documents/ eurybase/ national summary_sheets/047_SE_EN.pdf

Eurydice. (2011). The Education System in Sweden. [Online] Retrieved on 28.January.2011, at URL: http://eacea.ec.europa.eu/education/eurydice/ documents/eurybase/ eurybasefull_reports/SE EN.pdf

Evaluation of Schools. (2004). Evaluation of Schools providing Compulsory Education in Europe. [Online] Retrieved on 08.November.2007, at URL: http://www.eurydice.org/ressources/ eurydice/pdf/0_integral/ 042EN.pdf

George, Nicholas ve Green, Miranda. (2004). Swedısh Educatıon System Provıdes Inspiration For Conservatıve Policy Proposals. Financial Times, Londra, 30.06.2004.

Government Offices of Sweden. (2010). Ministry of Education and Science Organisation. [Online] Retrieved on 24.September.2010, at URL: http://www.sweden.gov.se/sb/d/3008

Government Offices of Sweden. (2011a). Adult Learning. [Online] Retrieved on 31.January.2011, at URL: http:// www. sweden. gov.se/sb/d/6997

Government Offices of Sweden. (2011b). Education for Adults with Intellectual Impairment/Särvux. [Online] Retrieved on 31.January.2011, at URL:http://www.sweden.gov.se/sb/d/6997/a/67939

Government Offices of Sweden. (2011c). Swedish Tuition for Immigrants (sfi). [Online] Retrieved on 31.January.2011, at URL: http://www.sweden.gov.se/sb/d/6997/a/67940 
Government Offices of Sweden. (2011d). Government Agencies in the Area of Education. [Online] Retrieved on 31.January.2011, at URL: http://www.sweden.gov.se/sb/d/13673/a/153916

Government Offices of Sweden. (2011e). Responsibility for Schools in Sweden. [Online] Retrieved on 01.February.2011 http://www. sweden. gov.se/sb/d/8009/a/72375

Gülcan, M. G.. (2005). AB ve Eğitim Süreci. Ankara: Anı Yayıncılık.

Hsv. (2011). Swedish National Agency for Higher Education. [Online] Retrieved on 28.January.2011, at

URL: http://www.hsv.se/2.539a949110f3d5914ec800056285.html

Inca. (2010). International Review of Curriculum and Assessment Frameworks Internet Archive. [Online] Retrieved on 24.September.2010, at URL: http://www.inca.org.uk/sweden-organisation-mainstream.html

Inca. (2011). Sweden: Organisation / Control of Education System. [Online] Retrieved on 02. February.2011, at URL: http://www.inca.org.uk/swedenorganisation-mainstream.html

Insight. (2011). Sweden. [Online] Retrieved on 01.February.2011, at URL: http://insight.eun.

org/ www/en/pub/insight/misc/country_report.cfm?fuseaction=home.view_report\& country $=9294$

Kilimci, S. ve Riis, Ulla. (2008). Educational System In Sweden: Trends And Reforms. Ç.Ü. Sosyal Bilimler Enstitüsü Dergisi, Cilt 17, Sayı 2, ss.255-266.

Lundahl, L. (2005). A Matter of Self-Governance and Control. European Education, Volume: 37, No: 1, Spring 2005, pp. 10-25.

MEB DİGM. (2006). Türkiye ve Avrupa Birliği Ülkelerinin Ĕgitim Sistemleri. Ankara: MEB Dış İliş̧iler Genel Müdürlüğü Yayını.

MEB Rehber. (2006). Yurtdışı Eğitim Personeli Rehberi. Ankara: Milli Eğitim Bakanlığı Dış İlişsiler Genel Müdürlüğü.

MEB TKB. (2007). Türkiye ve Avrupa Birliği Ülkelerinde Eğitim Denetimi. Ankara: MEB Teftiş Kurulu Başkanlığı Yayını. s. 115 - 116.

OECD (2010). Education at a Glance 2009: OECD Indicators. [Online] Retrieved on 24.September.2010, at URL: http://www.oecd.org/dataoecd/17/31/39245343.xls

Reingen. (2011). Higher Education Institutions in Sweden. [Online] Retrieved on 28.January.2011, at URL: http://www.regeringen.se/sb/d/6943

Skolinspektionen. (2011a). The Inspectorate of Educational Inspection of Sweden. [Online] Retrieved on 02 February 2011, at URL: http://www.skolinspektionen.se/PageFiles/1854/SwedishSchoolsInspectorate2009.pdf

Skolinspektionen. (2011b). About the Swedish Schools Inspectorate. [Online] Retrieved on 02.February.2011, at URL: http://www.skolinspektionen.se/en/AboutSkolinspektionen/About-the-Swedish-Schools-Inspectorate

Skolinspektionen. (2011c). The activities of the Schools Inspectorate. [Online] Retrieved on 02 February 2011, at URL: http://www.skolinspektionen.se/en/About-Skolinspektionen/The-activities-ofthe-School-Inspectorate/ 
Sverigeturism (2008). Compulsory Education. [Online] Retrieved on 12.January.2008, at URL: http://www.sverigeturism.se/smorgasbord/index.html Ulusavaş, M. (2000). Temel Yurttaşlık Eğitimi. Pamukkale Üniversitesi IV. Ulusal Sınıf Öğretmenliği Sempozyumu, 15-16 Ekim 1998. Yayın: 2000.

Ültanır, Y. G. (2005). Türk Eğitim Sistemi ile Avrupa Birliği Ülkelerindeki Hümanist-Demokratik Eğitim Modelinin Karşılaştırması. Millî Eğitim Dergisi, 33, 167. s. 110-153. 
